\title{
PENCABUTAN HAK UNTUK MEMILIH DAN DIPILIH BAGI TERPIDANA TINDAK PIDANA KORUPSI
}

\author{
Denny Ardiansyah \\ Fakultas Hukum Universitas Boyolali \\ Jl. Pandanaran No. 405; Boyolali; 57315; Indonesia; (0276) 321328 \\ ardiansyahrecht@ymail.com
}

\begin{abstract}
The criminal act of corruption is a criminal act that has a tremendous impact on the stability of the nation and state. The impact of this criminal offense is highly systemic and incurs enormous losses in the state financial sector. some cases occurred an ex-convict corruption case, when it was out of running his penalty, it turns out to be more officials in the environment of his service. The purpose of this study is first to examine or analyze the formulation policy of revocation of the Right to be elected and vote for convicted corruption, both reviewing or analyzing the policies that can be applied in the formulation in the future. The research method used in this legal research is juridical-normative. Whereas in essence the regulation concerning additional crime shall be the revocation of certain rights including the right to be elected and to vote already regulated by the laws and regulations in Indonesia. Although there has been renewal in the draft law the additional criminal provisions may stand on its own, but the right to vote and vote is unclear, so there is still a gap for corrupt criminals who can be public officials again.
\end{abstract}

Keywords: The Lifting of Rights, Convict, Corruption.

\begin{abstract}
Abstrak
Tindak pidana korupsi merupakan tindak pidana yang sangat berdampak luar biasa dalam stabilitas bangsa dan negara. Imbas dari tindak pidana ini sangat sistemik dan menimbulkan kerugian yang sangat besar dalam sektor keuangan negara. beberapa kasus terjadi seorang mantan narapidana kasus korupsi, ketika sudah keluar dari menjalankan pidanannya, ternyata justru menjadi pejabat lagi di lingkungan dinasnya. Tujuan penelitian ini pertama untuk mengkaji atau menganalisis mengenai kebijakan formulasi pencabutan Hak untuk dipilih dan memilih bagi terpidana korupsi, kedua mengkaji atau menganalisis kebijakan-kebijakan yang dapat diterapkan dalam formulasi di masa mendatang. Metode penelitian yang digunakan dalam penelitian hukum ini adalah yuridis-normatif. Bahwa pada dasarnya pengaturan mengenai pidana tambahan berupa pencabutan hak-hak tertentu termasuk hak untuk dipilih dan memilih sudah diatur peraturan perundang-undangan di Indonesia. Walaupun sudah terdapat pembaharuan di dalam rancangan undang-undang pada ketentuan pidana tambahan dapat berdiri sendiri, namun terkait hak memilih dan dipilih masih belum jelas, sehingga masih ada celah bagi koruptor yang selesai menjalani pidana bisa menjadi pejabat publik lagi.
\end{abstract}

Kata Kunci: Pencabutan Hak, Terpidana, Tindak Pidana Korupsi. 


\section{Pendahuluan}

Pasca runtuhnya orde baru, indonesia mengalami era reformasi dengan melakukan berbagai perubahan dan pembangunan pada aspek kehidupan dalam berbangsa dan bernegara, serta termasuk juga perubahan dan pembangunan dalam bidang penegakan hukum. Salah satu yang menjadi perhatian pemerintah adalah penegakan hukum dalam bidang tindak pidana korupsi.

Tindak pidana korupsi merupakan tindak pidana yang sangat berdampak luar biasa dalam stabilitas bangsa dan negara. Karena imbas dari tindak pidana ini sangat sistemik dan menimbulkan kerugian yang sangat besar dalam sektor keuangan negara. Hal inilah yang mengakibatkan suatu bangsa tidak bisa berkembang mengikuti kemajuan zaman.

Perbuatan korupsi tergolong sebagai white collar crime yang diartikan Sutherland sebagai crime commited by person of respectability and high social status in the course of their occupation (kejahatan yang dilakukan oleh orang-orang yang memiliki kedudukan sosial yang tinggi dan terhormat dalam pekerjaannya) (Ali, 2008), sebagai occupational crime perbuatan yang dilakukan oleh pejabat atau birokrat ini berkaitan dengan tindakan sewenangwenang yang dapat merugikan masyarakat, korupsi, manipulasi, kolusi, dan berbagai jenis kejahatan yang berkaitan dengan kekuasaan yang dimiliki.

Sebagai extra ordinary crime, berbagai upaya pemberantasan tindak pidana korupsi selalu menjadi kajian utama dalam berbagai literatur. Selain itu juga, pemerintah pasca reformasi telah menerbitkan Undang-Undang Republik Indonesia Nomor 31 Tahun 1999 Jo. Undang-Undang Republik Indonesia Nomor 20 Tahun 2001 Tentang Pemberantasan Tindak Pidana Korupsi. Selain itu juga pada tahun 2002 juga telah dibentuk lembaga Komisi Pemberantasan Korupsi (KPK). KPK adalah suatu lembaga ad hoc yang dibentuk khusus untuk menangani permasalahan korupsi di negeri ini.
Sejak dibentuk KPK telah menangani sedikitnya 385 kasus tindak pidana korupsi. Sejumlah keseluruhan perkara yang ditangani KPK tersebut, masing-masing melibatkan anggota DPR dan DPRD sebanyak 72 kasus, kepala lembaga/kementerian sebanyak 9 kasus, duta besar sebanyak 4 kasus dan komisioner terdapat 7 kasus. Selain itu terdapat juga 34 kasus yang melibatkan walikota/ bupati dan wakil bupati, kemudian untuk pejabat eselon I, II, III juga terlihat dominan dengan jumlah 144 kasus, selain itu terdapat juga hakim 8 kasus, swasta 87 kasus dan lainnya 41 kasus (Republika, 2014). Jumlah kasus ini belum termasuk kasus korupsi yang ditangani oleh penyidik kepolisian dan penyidik kejaksaan.

Melihat data banyaknya kasus korupsi yang menjerat pejabat negara, ini membuktikan bahwa penegakan tindak pidana korupsi di Indonesia sedang gencar-gencarnya dilakukan demi menyelamatkan negara. Namun walaupun aparat penegak hukum sudah bekerja keras dalam mengungkap kasus korupsi, kenyataan di lapangan masih terdapat koruptor-koruptor baru yang lahir menggerogoti uang negara. Seolah tidak belajar dari terpidana koruptor yang dijebloskan oleh KPK ke lembaga Pemasyarakatan, namun justru semakin berani melakukan perbuatannya.

Melihat realitas tersebut, berbagai upaya dilakukan oleh aparat penegak hukum, mulai dari pemiskinan koruptor hingga usulan dilakukannya kerja sosial bagi pelaku korupsi sebagai efek jera. Namun hal itu masih saja tidak menghentikan perilaku korup oleh pejabat di negeri ini. Bahkan yang mengejutkan, dalam beberapa kasus terjadi seorang mantan narapidana kasus korupsi, ketika sudah keluar dari menjalankan pidanannya, ternyata justru menjadi pejabat lagi di lingkungan dinasnya. Sebagai contoh, "Azirwan mantan terpidana korupsi dengan vonis 2 tahun 6 bulan penjara kasus suap anggota Komisi IV Al Amin Nasution. Sebelum menggundurkan diri atas desakan masyarakat, ia menjabat sebagai Kepala Dinas Kelautan dan Perikanan Provinsi Kepulauan Riau. Sedangkan di kabupaten Lingga eks 
terpidana korupsi masih menjabat Kepala Dinas Pekerjaan Umum dan Perhubungan, Kepala Dinas Pertanian dan Perkebunan, Kepala Badan Arsip dan Perpustakaan." (Negara Hukum, 2014).

Kasus di lingkungan Pemkot Tanjung balai di daerah Sumatera Utara "Seperti yang terjadi di Pemerintahan Kota (Pemko) Tanjungbalai yang dipimpin oleh Walikota dan Wakil walikotanya Drs.H.Thamrin Munthe M.Hum-Rolel harahap SE yang mengangkat seorang PNS terpidana korupsi Sumiran SH menjadi Kepala Dinas Pengelolaan Pendapatan, Keuangan dan Asset Daerah (PPKAD) di Pemko Tanjungbalai. Kadis PPKAD Pemko Tanjungbalai ini sesuai dengan yang dilansir oleh kelompok Mahasiswa Kota Tanjungbalai melalui selebarannya menyebutkan Sumiran SH adalah mantan Kepala Dinas Keuangan di Pemerintahan Kabupaten (Pemkab) Mandailing Natal (Madina) yang pernah dijatuhi hukuman penjara oleh Pengadilan negeri Tapanulisi Selatan (Tapsel) dengan Nomor Putusan: 126/ Pid.B/2002/PN.P.P.Pyb. dalam kasus korupsi yang dilakukannya di Dinas keuangan Pemkab Madina" (Kompasiana, 2014), yang terakhir terdapat juga kasus kepala daerah terpidana korupsi bisa terpilih lagi "selama ini pelaku korupsi kerap mendapatkan posisi politik yang bagus setelah menjalani masa hukuman. Dia mencontohkan dalam kasus di Boven Digoel, Papua dan Tomohon, Sulawesi Utara. Pelaku sudah dihukum, tetapi menang lagi dalam proses pemilihan kepala daerah berikutnya" (Antikorupsijateng, 2014).

Beberapa kasus yang dipaparkan, terlihat bahwa masih terdapat celah bagi mantan narapidana koruptor untuk bisa eksis lagi menjadi seorang pegawai pemerintahan bahkan menjadi pejabat. Hal ini sungguh mencederai perasaan rakyat dimana keadaan masyarakat indonesia sebagian besar masih dibawah garis kemiskinan, namun justru perampok uang negara bisa melenggang bebas kembali menduduki jabatan di pemerintahan.

Akhir tahun 2013 terdapat terobosan hukum yang dilakukan KPK terhadap kasus simulator sim yaitu menuntut untuk diberikannya pidana tambahan bagi terdakwa Inspektur Jenderal Djoko Susilo. Dan majelis hakim pun mengabulkan tuntutan KPK. Berikut kutipan putusan majelis hakim tipikor Pengadilan Tinggi Jakarta pada hari Rabu, 18 Desember 2013;

1. Menyatakan Terdakwa Inspektur Jenderal Polisi Drs. Djoko Susilo, SH., M.Si.,telah terbukti secara sah dan menyakinkan menurut hukum bersalah melakukan Tindak Pidana Korupsi secara bersama-sama dan gabungan beberapa kejahatan serta Tindak Pidana Pencucian Uang secara bersama-sama dan Gabungan beberapa kejahatan;

2. Menjatuhkan pidana terhadap Terdakwa berupa pidana penjara selama 18 tahun dan pidana denda sebesar Rp. 1.000.000.000 (satu milyar rupiah), subsidair 1 tahun kurungan;

3. Menghukum Terdakwa untuk membayar uang pengganti sebesar Rp. 32.000.000.000 (tiga puluh dua milyar rupiah), dan apabila Terdakwa tidak membayar uang pengganti dalam waktu 1 bulan setelah putusan memperoleh kekuatan hukum tetap, maka harta bendanya dapat disita oleh Jaksa dan dilelang untuk menutupi uang pengganti tersebut. Apabila harta bendanya tidak mencukupi, maka dijatuhi pidana penjara selama 5 tahun;

4. Menghukum Terdakwa dengan pidana tambahan berupa pencabutan hak-hak tertentu untuk memilih dan dipilih dalam jabatan publik; (Pengadilan Tinggi Jakarta, 2014).

KPK melakukan sebuah terobosan dengan penambahan penuntutan yaitu dengan memasukkan pidana tambahan pencabutan hak-hak tertentu untuk dipilih dan memilih dalam jabatan publik bagi pelaku korupsi. Hal ini terjadi untuk pertama kalinya pada kasus korupsi mantan kepala Korps Lalu Lintas Polri Inspektur Jenderal Djoko Susilo.

\section{Metode Penelitian}

Metode penelitian yang digunakan dalam penelitian hukum ini adalah yuridis-normatif. 
Penelitian hukum normatif merupakan penelitian yang dilakukan dengan cara meneliti bahan pustaka. Metode pendekatan yang digunakan adalah yang berorientasi pada kebijakan (policy oriented approach). Sumber data berasal dari data sekunder (bahan pustaka), yakni data yang diperoleh dari bahan pustaka meliputi Kitab Undang-Undang Hukum Pidana (KUHP), RKUHP, Undang-Undang Republik Indonesia Nomor 31 Tahun 1999 Tentang Pemberantasan Tindak Pidana Korupsi, KUHP Asing meliputi KUHP Norwegia. Metode pengumpulan data ditempuh dengan melakukan penelitian kepustakaan dan studi dokumen. Didalam pengumpulan data, sebanyak mungkin data yang diperoleh dan dikumpulkan diharapkan sesuai dengan permasalahan yang berhubungan dengan penelitian ini.

Model Analisis yang dilakukan adalah Yuridis Komparatif, yaitu dengan membandingkan kebijakan legislatif negara-negara lain dalam memformulasikan mengenai pencabutan hak memilih dan dipilih, kemudian juga melakukan Analisis Yuridis Preskriptif, untuk mengkaji kebijakan formulasi hukum pidana yang akan datang dalam memformulasikan mengenai pencabutan hak memilih dan dipilih.

\section{Hasil Penelitian dan Pembahasan}

\section{A. Kebijakan Formulasi Penjatuhan Pidana Tambahan "Pencabutan Hak-Hak Tertentu untuk Dipilih dan Memilih Dalam Jabatan Publik"}

Secara harfiah, "public office" merupakan jabatan publik atau jabatan umum, yaitu suatu posisi yang berhubungan dengan rakyat sebagai keseluruhan (a position concerning the people as a whole). Namun sebagai istilah hukum, perkataan "public office" ini mengandung muatan mulai dari pengertian yang paling sempit sampai yang paling luas. Dalam pengertian yang sempit, istilah ini biasa dikaitkan dengan pengertian "pejabat negara" yang secara administrasi ditentukan secara limi- tatif sebagai pejabat negara berdasarkan Peraturan Pemerintah yang khusus karena berhubungan dengan ketentuan mengenai hak administratif berupa tunjangan keuangan dan hak-hak protokoler (Ashiddiqie).

Sedangkan secara umum, "public office" memang biasa diartikan sebagai "a position or occupation established by law or by the act of a government body, for the purpose of exercising the authority of the government in the service of the public". Namun dalam praktik di Amerika Serikat seperti tercermin dalam berbagai putusan pengadilan, pengertian "public office" dapat juga dipahami secara lebih terbatas. Pertama, "public officer" dibedakan dari "public employee". Kedua, pemegang jabatan publik ditentukan berdasarkan kewenangannya untuk membuat keputusan atas nama negara atau kepentingan publik. Jika jabatan dimaksudkan hanya bersifat "advisory" yang berisi pertimbangan yang tidak mengikat atau rekomendasi yang tidak memaksa dalam proses pengambilan keputusan, jabatan tersebut tidak dipandang sebagai "public office" (Ashiddiqie).

Tujuan hukum pidana tidak identik dengan hal yang berkaitan dengan pengenaan sanksi pidana, tetapi merupakan upaya represif yang kuat berupa tindakan-tindakan pengamanan. Tindak pidana perlu dijatuhkan kepada terdakwa karena telah melanggar hukum (pidana).

Penjatuhan pidana dipandang sebagai suatu hal yang berupa nestapa yang dapat dikenakan kepada pembuat karena melakukan suatu delik. Hal ini bukan merupakan tujuan akhir hukum pidana namun sebagai tujuan terdekat. Inilah perbedaan antara pidana dan tindakan karena tindakan dapat berupa nestapa juga, tetapi bukan tujuan. Tujuan akhir pidana dan tindakan dapat menjadi satu, yaitu memperbaiki pelaku tindak pidana.

KUHP indonesia mengenal 2 kelompok jenisjenis pidana, yaitu pidana pokok dan pidana tambahan. Menurut Pasal 10 KUHP Pidana Pokok 
terdiri dari; 1) Pidana mati 2) Pidana penjara 3) Pidana kurungan 4) Pidana denda 5) Pidana tutupan (ditambahkan berdasarkan UU No. 20 Tahun 1946). Kemudian untuk pidana tambahan adalah pencabutan hak-hak tertentu seperti; 1) Perampasan barang-barang tertentu dan, 2) Pengumuman putusan Hakim.

Menurut ketentuan Pasal 35 ayat (1) KUHP hak-hak yang dapat dicabut oleh hakim dengan suatu putusan pengadilan adalah: 1) Hak memegang jabatan pada umumnya atau jabatan yang tertentu, 2) Hak untuk memasuki angkatan bersenjata, 3) Hak memilih dan dipilih dalam pemilihan yang diadakan berdasarkan aturan-aturan umum, 4) Hak menjadi penasehat atau pengurus atas penetapan pengadilan, hak menjadi wali, wali pengawas, pengampu atau pengampu pengawasan atas orang yang bukan anak sendiri, 5) Hak menjalankan kekuasaan bapak, menjalankan perwalian atau pengampuan atas anak sendiri, 6) Hak menjalankan mata pencarian tertentu.

Pencabutan hak, Pasal 38 ayat (1) KUHP mengatur bahwa hakim menentukan lamanya pencabutan hak sebagai berikut; 1) Dalam hal pidana mati atau pidana penjara seumur hidup, maka lamanya pencabutan adalah seumur hidup, 2) Dalam hal pidana penjara untuk waktu tertentu atau pidana kurungan, lamanya pencabutan paling sedikit dua tahun dan paling banyak lima tahun lebih lama dari pidana pokoknya, 3) Dalam hal pidana denda, lamanya pencabutan paling sedikit dua tahun dan paling banyak lima tahun. Ayat (2) menyatakan bahwa Pencabutan hak itu mulai berlaku pada hari putusan hakim dapat dijalankan. Dalam hal ini hakim tidak berwenang memecat seorang pejabat dari jabatannya jika dalam aturanaturan khusus ditentukan penguasa lain untuk pemecatan itu.

Sementara itu di dalam Undang-Undang Republik Indonesia Nomor 31 tahun 1999 jo. Undang-Undang Republik Indonesia Nomor 20 tahun 2001 tentang pemberantasan tindak pidana korupsi juga sudah terdapat ketentuan mengenai penjatuhan pidana tambahan, Pasal 18 ayat (1) menyatakan bahwa Selain pidana tambahan sebagaimana dimaksud dalam Kitab Undang-Undang Hukum Pidana, sebagai pidana tambahan adalah: a) Perampasan barang bergerak yang berwujud atau yang tidak berwujud atau barang tidak bergerak yang digunakan untuk atau yang diperoleh dari tindak pidana korupsi, termasuk perusahaan milik terpidana di mana tindak pidana korupsi dilakukan, begitu pula dari barang yang menggantikan barang-barang tersebut, b) Pembayaran uang pengganti yang jumlahnya sebanyak-banyaknya sama dengan harta benda yang diperoleh dari tindak pidana korupsi, c) Penutupan seluruh atau sebagian perusahaan untuk waktu paling lama 1 (satu) tahun d) Pencabutan seluruh atau sebagian hak-hak tertentu atau penghapusan seluruh atau sebagian keuntungan tertentu, yang telah atau dapat diberikan oleh Pemerintah kepada terpidana.

Ayat (2) menyatakan bahwa Jika terpidana tidak membayar uang pengganti sebagaimana dimaksud dalam ayat (1) huruf b paling lama dalam waktu 1 (satu) bulan sesudah putusan pengadilan yang telah memperoleh kekuatan hukum tetap, maka harta bendanya dapat disita oleh jaksa dan dilelang untuk menutupi uang pengganti tersebut. Terakhir ayat (3) menyatakan bahwa dalam hal terpidana tidak mempunyai harta benda yang mencukupi untuk membayar uang pengganti sebagaimana dimaksud dalam ayat (1) huruf $b$, maka dipidana dengan pidana penjara yang lamanya tidak melebihi ancaman maksimum dari pidana pokoknya sesuai dengan ketentuan dalam Undangundang ini dan lamanya pidana tersebut sudah ditentukan dalam putusan pengadilan.

Putusan pengadilan dalam kejahatan korupsi hendaknya mencerminkan nilai-nilai yang terkadung dalam Pancasila untuk terciptanya keadilan sesungguhnya. Penerapan Pancasila ini sebagai perwujudan negara hukum Pancasila dalam proses peradilan dapat dicapai dengan menerapkan prinsip- 
prinsip dan asas-asas persidangan yang baik sesuai dengan nilai-nilai Pancasila. (Sunarjo, 2014). Oleh karena itu penerapan asas Pancasila ini sebagai dasar penguat hakim dalam menjatuhkan pidana tambahan.

Pidana tambahan pada dasarnya merupakan pidana yang bersifat menambah pidana pokok yang dijatuhkan, serta tidak dapat berdiri sendiri kecuali dalam hal-hal tertentu. Selain itu juga pidana tambahan ini bersifat fakultatif artinya dapat dijatuhkan tetapi tidaklah harus (Setiady, 2010). Berkaitan dengan pencabutan Hak-hak tertentu dalam sejarahnya, sanksi ini sudah dapat kita temukan dalam hukum romawi. Misalnya di sini infamia (hilangnya sejumlah hak istimewa sebagai warga Romawi atau hilangnya kehormatan), deminutio existimationis (pengurangan kehormatan) yang dijatuhkan terhadap perbuatan melakukan pekerjaan-pekerjaan tidak terhormat, termasuk pada pelanggaran kontrak, dan juga berhubungan dengan vonis terhadap sejumlah kejahatan tertentu (Remmelink, 2003). Cirinya adalah bahwa hukuman demikian tidak dijatuhkan melainkan berlaku secara otomatis dan sejauh mungkin berupaya mewujudkan restitutioin integrum yang kadang berarti seumur hidup. Hukuman ini berwujud pencabutan keseluruhan hak privat maupun publik terpidana.

Kanter dan Sianturi (2002), juga mengingatkan pencantuman pidana tambahan dalam Buku I KUHP tidak berarti bahwa pidana tambahan dapat ditambahkan untuk setiap pemidanaan. HB Vos mengatakan bahwa pidana pencabutan hak-hak tertentu berada di ranah kehormatan, yang membedakannya dari pidana hilang kemerdekaan. Pertama, pencabutan hak tertentu tidak otomatis karena harus ditetapkan lewat putusan hakim. Kedua, tidak berlaku seumur hidup tetapi menurut jangka waktu menurut undang-undang dengan suatu putusan hakim (Hamzah, 2008).

Pencabutan hak tertentu hanya untuk delikdelik yang tegas ditentukan oleh undang-undang.
Kadang-kadang dimungkinkan oleh undangundang untuk mencabut beberapa hak bersamaan dalam suatu perbuatan seperti Pasal 350 KUHP. Pasal ini menyebutkan pada waktu menjatuhkan hukuman untuk perkara makar mati (doodslag), pembunuhan berencana (moord) atau karena salah satu kejahatan yang diterangkan Pasal 344, 347, dan 348, dapat dijatuhkan hukuman mencabut hakhak yang disebut dalam Pasal 35 KUHP.

Menurut Roeslan Saleh (1960), masuknya pencabutan hak tertentu dalam KUHP karena pembentuk undang-undang menganggap hukuman tambahan tersebut patut. Kepatutan bukan karena ingin menghilangkan kehormatan seseorang, melainkan karena alasan lain seperti pencegahan khusus. Misalnya, pencabutan hak seseorang menjadi dokter karena malpraktik. Maksud pencabutan hak tersebut adalah agar perbuatan serupa tidak lagi dilakukan lagi oleh pelaku tindak pidana atau seringkali dikenal dengan recidive.

\section{B. Kebijakan Formulasi Penjatuhan Pidana Tambahan Pencabutan Hak-Hak Tertentu untuk Dipilih dan Memilih Dalam Jabatan Publik Bagi Terpidana Korupsi}

Pidana tambahan berupa pencabutan hakhak tertentu bukanlah merupakan hal yang baru karena memang sudah terdapat di KUHP dan juga undang-undang tindak pidana korupsi. Namun selama ini baru pada kasus Irjen Djoko Susilo, hakim memutuskan untuk memberikan pidana tambahan berupa pencabutan hak politik bagi pelaku tindak pidana korupsi. Sedangkan pada kasus yang baru tahun 2014 ini, KPK kembali menuntut seorang terdakwa koruptor yaitu Akil Muchtar dengan pidana tambahan pencabutan hak-hak tertentu, namun majelis hakim PN Jakarta Pusat tidak menjatuhkan putusan sebagaimana dituntut oleh Jaksa KPK.

Sebagai kejahatan yang luar biasa, oleh karena itu dalam penanganan tindak pidana korupsi harus lah dengan cara-cara yang luar biasa pula. Dalam praktiknya tindak pidana korupsi 
sering diidentikkan oleh penyalahgunaan kekuasaan dari pejabat yang berwenang demi mendapatkan keuntungan secara pribadi. Hal ini persis seperti yang disampaikan Kartono dalam (Ravida, 2003) bahwa korupsi sebagai tingkah laku individu yang menggunakan wewenang dan jabatan guna mengeduk keuntungan pribadi, merugikan kepentingan umum dan negara. Jadi korupsi merupakan gejala salah pakai dan salah urus dari kekuasaan, demi keuntungan pribadi, salah urus terhadap sumber-sumber kekayaan negara dengan menggunakan wewenang dan kekuatan-kekuatan formal (misalnya dengan alasan hukum dan kekuatan senjata) untuk memperkaya diri sendiri.

Melihat realitas yang terjadi mengenai tindak pidana korupsi yang memang sering kali merupakan sebuah kejahatan yang dilakukan dalam jabatan, dan hingga faktanya bahwa terpidana korupsi yang sudah bebas masih bisa melenggang bebas menduduki suatu jabatan tertentu dalam pemerintahan, tentunya kita tidak bisa tinggal diam melihat permasalahan ini. Menurut Adami Chazawi, (2002) teori pemidanaan dikenal teori relatif atau teori tujuan, teori ini berpokok pangkal pada dasar bahwa pidana adalah alat untuk menegakkan tata tertib (hukum) dalam masyarakat. Tujuan pidana ialah tata tertib masyarakat, dan untuk menegakkan tata tertib itu diperlukan pidana. Pidana adalah alat untuk mencegah timbunya suatu kejahatan dengan tujuan agar tata tertib masyarakat tetap terpelihara. Ditinjau dari sudut pertahanan masyarakat itu tadi, maka pidana itu adalah suatu yang terpaksa perlu (noodzakelijk) diadakan.

Dilihat dari sifat pencegahannya, teori relatif mempunyai 2 macam sifat, yaitu pencegahan umum (generale preventie) dan pencegahan khusus (speciale preventiae). Diantara teori-teori pencegahan umum ini, teori pidana yang bersifat menakutnakuti adalah teori yang paling lama dianut orang. Menurut teori ini, pidana yang dijatuhkan pada penjahat ditujukan agar orang-orang (umum) men- jadi takut untuk berbuat kejahatan (Chazawi, 2002). Dalam beberapa kasus tindak pidana korupsi, pidana yang dijatuhkan selama ini hanya bersifat pidana badan, namun belum menyentuh ke dalam aspek setelah seorang terpidana menjalankan pidananya. Hingga pada akhirnya dalam beberapa kasus terpidana koruptor selesai menjalani masa pidana, masih bisa kembali lagi menjadi seorang pejabat pemerintahan. Hal ini akhirnya kurang memberikan efek jera karena koruptor sendiri masih diberi kesempatan bekerja di pemerintahan.

Diperlukan upaya penalisasi dan depenalisasi yang efektif untuk menanggulangi tindak pidana korupsi, karena penjatuhan pidana selain bertujuan memberikan nestapa kepada pelaku juga sebagai upaya pencegahan tindak pidana korupsi. Penalisasi merupakan proses kebijakan legislasi tentang sistem penjatuhan sanksi pidana. Apakah suatu perbuatan (jahat), tindak pidana itu perlu diancam dengan sanksi pidana atau tidak (sanksi non penal) merupakan hal penting dalam pertimbangannya. Jadi penalisasi itu merupakan wujud dari kebijakan legislasi yang mengancam pidana terhadap perbuatan pidana (Setiyono, 2016).

Dengan demikian dalam suatu keadaan penalisasi dapat dikatakan sama dengan kriminalisasi, tetapi dalam keadaan lain penalisasi tidak sama dengan kriminalisasi, karena ada perbuatanperbuatan yang dikriminalisasi tetapi tidak dipenalisasikan, melainkan dengan jenis sanksi yang lain yang bersifat non penal, yaitu dengan tindakan (maatregel). Sebaliknya, depenalisasi itu merupakan proses menghilangkan sanksi yang bersifat menghukum (pidana). Semula suatu perbuatan pidana atau tindak pidana tersebut diancam dengan sanksi pidana dirubah menjadi perbuatan pidana atau tindak pidana yang tidak diancam dengan sanksi pidana, melainkan diberi sanksi lain yang lebih bersifat edukatif dan humanis sehingga diharapkan pelaku tindak pidana tersebut bisa pulih kembali menjadi manusia yang baik dalam kehidupan masyarakat. Jadi dalam depenalisasi itu 
sifat perbuatan si pelaku tetap merupakan perbuatan yang bersifat melawan hukum, tetap merupakan perbuatan pidana, namun terhadap perbuatan pidana tersebut tidak dijatuhkan sanksi pidana, melainkan diberi sanksi tindakan atausanksi lain yang bersifat mendidik (Setiyono, 2016).

Berkaitan dengan penjatuhan pidana tambahan berupa pencabutan hak-hak dipilih dan memilih atau biasa disebut hak politik untuk menduduki jabatan tertentu, hal ini haruslah menjadi konsen bersama untuk dirumuskan kembali sebagai pembaharuan hukum pidana terkhusus dikenakan terhadap pelaku tindak pidana korupsi. Pencabutan hak memilih dan dipilih meliputi hak pilih aktif dan pasif. Ada perbedaan KUHP Indonesia dengan WvS Belanda. KUHP Indonesia kata "pemilihan" lebih luas pengertiannya karena merujuk pada peraturan umum, tidak dikatakan pemilihan menurut ketentuan Undang-Undang.

Utrecht menjelaskan masalah ini lebih gamblang, redaksi WvS 1915 -kemudian menjadi KUHP Indonesia - menggunakan kalimat 'krachtens algeemene verordeningen gehouden verkiezingen', sedangkan Wvs Belanda memuat kalimat 'krachtens wettelijk voorschrift uitgeschreven verkiezingen'. Jadi, menurut Utrecht (1999), di Indonesia bukan mengenai apakah hak pilih aktif dan hak pilih pasif itu ditentukan dalam suatu peraturan umum yang dibuat pemerintah pusat/daerah, residen, atau hukum adat. Cukup jika pemilihan itu didasarkan pada suatu peraturan umum yang dibuat oleh pemerintah pusat dan kemudian digunakan sebagai dasar suatu peraturan daerah atau mengakui dan memperkuat suatu peraturan hukum adat.

Beberapa KUHP Asing yang memuat mengenai pidana tambahan ada beberapa yang bisa menjadi bahan rujukan sebagai bahan pembaharuan. KUHP Norwegia terdapat pidana tambahan (supplementary punishment) yang diatur dalam Pasal 16 dan salah satunya terdiri dari deprivation of right (perampasan hak) berupa hak menjadi anggota angkatan bersenjata (diatur dalam Pasal 30) dan hak untuk memilih dan dipilih (Pasal 31) (Arief, 2010). Namun sebagai catatan, menurut Barda Nawawi Arief (2010), dalam pasal 15 yang mengatur pidana pokok ada ketentuan bahwa dalam keadaan-keadaan khusus seseorang dapat dikenakan pidana pencabutan hak-hak tertentu (deprivation of certain rights) seperti tersebut dalam Pasal 29 yaitu berupa; a) Kehilangan hak untuk jabatanjabatanumum/pemerintahan (loss of public office), b) Kehilangan hak untuk memegang jabatan atau meneruskan pekerjaan tertentu (loss of the right to hold office or to pursue a certain occupation). Menurut Pasal 15, jenis pidana ini (loss of right/ deprivation of right) dapat sebagai pidana yang berdiri sendiri disamping pidana lain atau sebagai pidana pengganti (in addition to or instead of other punishment).

Hal ini lah yang seharusnya bisa menjadi bahan pembaharuan berkaitan dengan pencabutan hak untuk dipilih dan memilih atau hak untuk memegang jabatan tertentu. Di Indonesia sendiri terkait dengan pidana tambahan pencabutan hakhak tertentu sudah diformulasikan dalam Rancangan Undang-Undang Kitab Undang-Undang Hukum Pidana tahun 2012 (RUU KUHP 2012) pada Pasal 67 bukan sebagai pidana tambahan yang bersifat fakultatif, namun pidana tambahan tersebut bisa berdiri sendiri. Berikut ketentuan dalam Pasal 67 RUU KUHP 2012 ayat (1) Pidana tambahan terdiri atas; pencabutan hak tertentu, perampasan barang tertentu dan/atau tagihan, pengumuman putusan hakim, pembayaran ganti kerugian, dan pemenuhan kewajiban adat setempat atau kewajiban menurut hukum yang hidup dalam masyarakat. Ayat (2) Pidana tambahan dapat dijatuhkan bersama-sama dengan pidana pokok, sebagai pidana yang berdiri sendiri atau dapat dijatuhkan bersama-sama dengan pidana tambahan yang lain, ayat (3) Pidana tambahan berupa pemenuhan kewajiban adat setempat atau kewajiban menurut hukum yang hidup dalam masyarakat atau pencabutan hak yang diperoleh korporasi dapat dijatuhkan walaupun tidak tercantum dalam perumusan tindak pidana, ayat (4) Pidana tambah- 
an untuk percobaan dan pembantuan adalah sama dengan pidana tambahan untuk tindak pidananya, ayat (5) Anggota Tentara Nasional Indonesia yang melakukan tindak pidana dapat dikenakan pidana tambahan sebagaimana diatur dalam peraturan perundang-undangan bagi Tentara Nasional Indonesia.

RUU KUHP 2012 sudah memperbaharui mengenai pencabutan hak tertentu yang dapat berdiri sendiri, selain itu juga pada Pasal 92 memang sudah mengkualifikasikan bahwa penjatuhan pidana tambahan pencabutan hak-hak tertentu yaitu hak untuk memegang suatu jabatan tertentu, namun terkait hak memilih dan dipilih masih berupa sebuah pidana tambahan yang bersifat umum. Serta pada akhirnya hal ini menjadi kewenangan dari aparat penegak hukum sendiri apakah mau diterapkan atau tidak, sehingga esensinya menjadi tidak jauh berbeda dari KUHP saat ini karena kurang menekankan sebuah kewajiban dalam menerapkannya terkhusus terhadap terpidana kasus tindak pidana korupsi.

Dengan dicabutnya hak politik bagi terpidana korupsi, tentunya mencegah perbuatan serupa terulang lagi, sehingga peluang-peluang bagi recidive tindak pidana korupsi menjadi tertutup. Selain itu perlu dipertimbangkan juga untuk mencabut tunjangan pensiun bagi mantan pejabat yang terbukti melakukan tindak pidana korupsi, agar dapat menimbulkan efek jera sekaligus shock terapy bagi pejabat yang lain agar tidak melakukan tindak pidana korupsi. Hal ini juga berlaku terhadap partai politik sebagai produsen utama pejabat publik yang menempati posisi-posisi strategis dalam lembaga pemerintahan untuk transparan dan akuntabel dalam pengelolaan keuanganya sehinga terwujud tata kelola partai politik yang baik sehinga mencegahpula terjadinya tindak pidana korupsi (Nahuddin, 2015).

\section{Kesimpulan}

Berdasarkan hasil penelitian dan pembahasan, dapat disimpulkan Bahwa pertama, pada dasar- nya pengaturan mengenai pidana tambahan berupa pencabutan hak-hak tertentu termasuk hak untuk dipilih dan memilih sudah diatur didalam KUHP dan Undang-Undang Republik Indonesia No. 31 tahun 1999 tentang pemberantasan tindak pidana korupsi. Kedua Bahwa walaupun sudah terdapat pembaharuan di dalam RUU KUHP 2012 pada ketentuan pidana tambahan dapat berdiri sendiri, namun terkait hak memilih dan dipilih masih belum jelas, sehingga masih ada celah bagi koruptor yang selesai menjalani pidana bisa menjadi pejabat publik lagi.

\section{DAFTAR PUSTAKA}

Ali, Mahrus. 2008. Kejahatan Korporasi. Arti Intan Bumi Intaran. Yogyakarta.

Anti Korupsi Jateng. 2013. Tak Cukup Dimiskinkan Cabut Pula Hak Politik Koruptor. (online) http:// antikorupsijateng.wordpress.com/2013/12/23/ tak-cukup-dimiskinkan-cabut-pula-hak-politikkoruptor/ (Diakses 10 Juli 2014).

Arief, Barda Nawawi. 2010. Perbandingan Hukum Pidana. Raja Grafindo Persada. Jakarta.

Chazawi, Adami. 2002. Pelajaran Hukum Pidana Bagian 1. Raja Grafindo Persada. Jakarta.

Erika, Ravida. 2003. Korupsi Di Indonesia, Masalah dan Solusinya. Fakultas Ilmu Sosial dan Ilmu Politik, Universitas Sumatera Utara. Medan.

Hamzah, Andi. 2008. Asas-Asas Hukum Pidana, edisi revisi. Rineka Cipta. Jakarta.

Kanter, E.Y. dan Sianturi, S.R. 2002. Asas-Asas Hukum Pidana di Indonesia dan Penerapannya. Storia Grafika. Jakarta.

Kitab Undang-Undang Hukum Pidana.

Kompasiana. 2012. Koruptor Jadi Pejabat Salah Siapa. (online). http://birokrasi.kompasiana.com/ 2012/11/10/koruptor-jadi-pejabat-salah-siapa502191.html (Diakses 10 Juli 2014).

Nahuddin, Y. (2017). Pertanggungjawaban Keuangan Partai Politik Menuju Tata Kelola Partai Politik yang Baik. Jurnal Cakrawala Hukum, 6 (2), 276-292. doi: 10.26905/idjch.v6i2.1462. 


\section{Jurnal Cakrawala Hukum}

Vol.8, No.2 Desember 2017: 139-148

Negara Hukum. Pencabutan Hak Sang Koruptor. (online). http://www.negarahukum.com/hukum/ pencabutan-hak-sang-koruptor.html (Diakses 10 Juli 2014).

Pengadilan Tinggi Jakarta. Putusan dalam Website Resmi Pengadilan Tinggi DKI Jakarta. (online). http:// www.ptjakarta.go.id/situs2/index.php?option= com_content\&view $=$ article\&id=331: sidangtindak-pidana-korupsi-inspektur-jenderal-polisidrs-djoko-susilo-sh-msi-pada-pengadilan-tindakpidana-korupsi-tingkat-banding-jakarta\&c atid=39:terbaru\&Itemid=229 (diakses 10 juli 2014).

Rancangan Undang-Undang Kitab Undang-Undang Hukum Pidana tahun 2012.

Remmelink, Jan., 2003. Hukum Pidana; Komentar atas pasalpasal terpenting Kitab Undang-Undang Hukum Pidana Belanda dan padanannya dalam Kitab UndangUndang Hukum Pidana Indonesia. Gramedia. Jakarta.

Republika. 2013. Sejak Berdiri KPK tercatat tangani 385 Kasus. (online). http://www.republika.co.id/ berita/nasional/hukum/13/09/26/mtqmnmsejak-berdiri-kpk-tercatat-tangani-385-kasus (diakses 10-juli-2014).
Saleh, Roeslan. 1960. Stelsel Pidana Indonesia. Yayasan Badan Penerbit Gadjah Mada. Yogyakarta.

Setiady, Tolib. 2010. Pokok-Pokok Hukum Penitensier Indonesia. Alfabeta. Bandung.

Setiyono, S. 2016. Reorientasi Kebijakan Pemidanaan Bagi Penyalahguna Narkotika. Jurnal Cakrawala Hukum, 7(1), 56-65. doi:10.26905/idjch.v7i1.1782

Sunarjo, S. 2017. Peradilan Sebagai Pilar Negara Hukum dalam Perspektif Pancasila. Jurnal Cakrawala Hukum, 19(1), 71-81. doi:10.26905/idjch.v19i1. 1132

Undang-Undang Republik Indonesia Nomor 31 Tahun 1999 Tentang Pemberantasan Tindak Pidana Korupsi.

\section{How to cite:}

Ardiansyah, Denny. 2017. Pencabutan Hak untuk Memilih dan Dipilih Bagi Terpidana Tindak Pidana Korupsi. Jurnal Cakrawalah Hukum, 8(2). 